\title{
Cellular fatty acid composition of symbiotic cyanobacteria isolated from the aquatic fern Azolla
}

\author{
Rodulio Caudales, ${ }^{*}$ John M. Wells ${ }^{2}$ and Alan D. Antoine ${ }^{1}$ \\ ${ }^{1}$ Department of Biochemistry and Microbiology, Lipman Hall, Cook College, Rutgers University, New Brunswick, \\ New Jersey 08903-0231, USA \\ ${ }^{2}$ Eastern Regional Research Center, US Department of Agriculture, 600 E. Mermaid Lane, Philadelphia, \\ Pennsylvania 19118, USA
}

(Received 2 April 1992; accepted 27 April 1992)

\begin{abstract}
The cellular fatty acid composition of 10 isolates of symbiotic cyanobacteria from 7 different species of the aquatic fern Azolla was investigated. Sixteen major components accounted for $88.31 \%$ of total fatty acids: the saturated 14:0, 16:0 and 18:0 carbon chains; the unsaturated straight-chained 12:1, 14:1 cis-7, 16:1 cis-7, 16:1 cis-9, 16:1 cis-11, 18:2 cis-9, 18:3 cis-9, 18:1 cis- and trans-9, and 20:4 cis-5; and the branch-chained iso-16:0. Also included was an unsaturated 16-carbon (equivalent carbon chain length of 15.5), with unsaturation sites undetermined. The most abundant component was the 16:0 (mean of $38.10 \%$ of the total). Thirty-six minor fatty acids, comprising $10.30 \%$ of the total, were detected and identified. These included hydroxy-substituted fatty acids (1.10\%), branched chains in addition to the iso-16:0 (1.96\% of a class total of $2.96 \%)$ and cyclopropane fatty acids $(0.89 \%)$. A comparison of the fatty acid profile of Azolla cyanobionts with those previously published for freeliving cyanobacteria of the genera Anabaena and Nostoc indicated that there were at least 19 individual fatty acids, class totals or ratios that were statistically different and could be used as differentiating factors. Nine of the 19 factors were characteristically unique to Azolla cyanobionts and different from both Anabaena and Nostoc. Five were different from only Anabaena, and five from only Nostoc. Based on one taxonomic interpretation of fatty acid analysis, the Azolla cyanobionts appeared to be equally distinct from Anabaena and from Nostoc.
\end{abstract}

\section{Introduction}

Azolla Lamarck, an aquatic fern widely distributed in tropical and subtropical regions is host to symbiotic, nitrogen-fixing cyanobacteria (Lumpkin \& Plucknett, 1982). Strasburger (1873) first described the Azolla cyanobiont, designating it Nostoc, and later renaming it Anabaena azollae (Strasburger, 1884). Its correct taxonomic classification has remained controversial.

The genera Anabaena and Nostoc have traditionally been differentiated by the morphology of a gelatinous sheath surrounding the trichomes, and by colony formation (Kirchner, 1900; Geitler, 1932). Rippka et al. (1979) suggested that the developmental life cycle should be the principal criterion in differentiating Nostoc from Anabaena. Reproduction in Anabaena is restricted to random fragmentation of trichomes or to germination of akinetes producing filaments of dimensions equal to

* Author for correspondence. Tel. (908) 932 9882; fax. (908) 932 8965. those of parent cells. All trichomes in Anabaena are capable of gliding motility. Hormogonia, motile filaments composed entirely of vegetative cells smaller than the parental cells and with gas vacuoles in some species, can develop from akinetes in the life cycle of Nostoc (Rippka et al., 1979; Castenholz, 1989; Meeks, 1990).

Cyanobacteria in the apex of Azolla fronds develop hormogonia as the main form of colonizing trichomes (Vashishta, 1975; Hill, 1975; Caudales et al., 1990). Hormogonia are produced in older leaf cavities by akinete germination or by differentiation of vegetative cells adjacent to single or double heterocysts (Caudales et al., 1990). Accordingly, based on these observations, on the criteria of Rippka et al. (1979) and Rippka (1988), and on the opinion of Peters \& Meeks (1989) and Meeks et al. (1988), the Azolla cyanobiont is more closely related to the genus Nostoc.

Caudales \& Wells (1992) reported that fatty acid composition was an effective taxonomic tool for differentiation between free-living Anabaena and Nostoc. The most useful parameters were the percentages of $16: 0$, of 
saturated even-carbon straight-chain fatty acids (class $\mathrm{A})$, and the ratio of unsaturated fatty acids (class $\mathrm{C}$ ) to class A.

In this report we analyse the fatty acid composition of Azolla cyanobionts, and its relationship to that of Anabaena and Nostoc.

\section{Methods}

Media and growth conditions. Ten Azolla accessions were grown in defined mineral medium without nitrogen, modified from Van Hove et al. (1983) consisting of $54.4 \mathrm{mg} \mathrm{KH} \mathrm{KO}_{4} \mathrm{1}^{-1}, 294 \mathrm{mg} \mathrm{CaCl}, 2 \mathrm{H}_{2} \mathrm{Ol}^{-1}$, $192 \mathrm{mg} \mathrm{MgSO}_{4} .7 \mathrm{H}_{2} \mathrm{Ol}^{-1}, 150 \mathrm{mg} \mathrm{KCl}^{-1}, 12 \mathrm{mg} \mathrm{NaCl}^{-1}, 12 \mathrm{mg} \mathrm{Fe}-$ EDTA $1^{-1}$ and $1 \mathrm{ml}$ trace metal mix A5 $1^{-1}$ (Rippka et al., 1979) plus $43.87 \mathrm{mg} \mathrm{CoCl}_{2} \cdot 6 \mathrm{H}_{2} \mathrm{O} \mathrm{l}^{-1}$. Photon flux density was $100 \mu \mathrm{mol} \mathrm{m} \mathrm{m}^{-2} \mathrm{~s}^{-1}$ from cool-white fluorescent and incandescent light, using a $14 / 10 \mathrm{~h}$ light/dark cycle. Temperature was $26 \pm 1{ }^{\circ} \mathrm{C}$ during the light and $16 \pm 1{ }^{\circ} \mathrm{C}$ during the dark periods. Names of the species, strains, geographical origins, and sources of accessions are listed in Table 1. Cyanobionts were harvested from 14-18 d old plants of 7 different Azolla species. Approximately $50 \mathrm{~g}$ of plants were washed in $0.2 \%$ sodium hypochlorite $+\mathbf{0 . 0 1} \%$ Triton for $20 \mathrm{~min}$, rinsed ten times with distilled water, and macerated in phosphate-free $\mathrm{BGI}_{0}$ medium (Rippka et al., 1979) with a blender. Cyanobacterial cells were separated from plant debris by dilution of the macerate in medium, filtration through 10 layers of cheesecloth, and by differential centrifugation. Pellets were resuspended in $\mathrm{BG} 11_{0}$ medium containing $2 \%(\mathrm{w} / \mathrm{v})$ each of pectinase and cellulase (Sigma) buffered at $\mathrm{pH} \mathrm{6.0}$ with $10 \mathrm{mM}$-MES, and incubated for $2 \mathrm{~h}$ at $30^{\circ} \mathrm{C}$. Pellets were then washed twice in medium, centrifuged at $500 \mathrm{~g}(10 \mathrm{~min})$, and fraction ated by density gradient centrifugation in $10-90 \%(w / v)$ Percoll at $2500 \mathrm{~g}$ (20 min). Prior to fatty acid analysis, cyanobacterial preparations were removed, examined microscopically at $500 \times$ for plant debris using a Zeiss Universal microscope (Zeiss Optics, New York) and again washed twice in medium. If debris was present (over 10-20 particles per field), Percoll centrifugation and washing was repeated.

As a control sample, a cyanobiont-free isolate of Azolla mexicana, obtained from Dr E. Braun-Howland (Rensselaer Polytech. Institute, Troy, NY, USA) was macerated, (wet) weighed, diluted logarithmically, and each dilution examined microscopically. Dilutions were selected which corresponded closest to contamination levels found in some cyanobiont preparations (about $10-50$ particles per microscopic field). These dilutions were then analysed for fatty acids to determine their contribution, if any, to cyanobiont profiles. Similarly, several types of bacteria from Azolla cavities, present as contaminants in some cyanobiont preparations, were cloned to single colonies, diluted to levels found in the preparations (less than 20 cells per field), and then analysed for fatty acids.

Fatty acid analysis. Approximately $400-500 \mathrm{mg}$ (wet wt) of cyanobacterial cells were saponified and esterified by mixing in $1 \mathrm{ml} 1.2 \mathrm{M}$ $\mathrm{NaOH}$ in $50 \%(\mathrm{v} / \mathrm{v})$ aqueous methanol, heating for $30 \mathrm{~min}$ in a boiling water bath, then adding $0.5 \mathrm{ml} 6 \mathrm{M}-\mathrm{HCl}$ and $1 \mathrm{ml} 12 \%(\mathrm{w} / \mathrm{v}) \mathrm{BCl}_{3}$ in methanol, and heating for $5 \mathrm{~min}$ at $85^{\circ} \mathrm{C}$. Methylated acids were then extracted with $1 \mathrm{ml}$ hexane-diethylether $(1: 1)$, washed with $3 \mathrm{ml} 0.3 \mathrm{M}$ $\mathrm{NaOH}$, and concentrated under a stream of purified, filtered $\mathrm{N}_{2}$ to approximately $20-40 \mu \mathrm{l}$. A $2 \mu \mathrm{l}$ sample was injected into a Varian 3700 Gas Chromatograph with a flame ionization detector and a $15 \mathrm{~m} \times 0.25 \mathrm{~mm}$ capillary glass column coated with SPB-1 (Supelco) as a non-polar stationary phase. Solvent blanks were checked periodically for impurities. Operating conditions were: helium carrier gas flow of

Table 1. Species and origin of Azolla host plants, and strain designations of their cyanobionts used in this study

\begin{tabular}{|c|c|c|c|}
\hline $\begin{array}{l}\text { Species } \\
\text { and } \\
\text { strain }\end{array}$ & $\begin{array}{c}\text { Original } \\
\text { strain } \\
\text { designation }\end{array}$ & Geographical origin & Source* \\
\hline A. caroliniana & & & \\
\hline $\mathrm{Cl}$ & $\mathrm{Cl}$ & Virginia, USA & G. Peters \\
\hline C8 & - & Río Chavón, Dominican Republic & Original isolate \\
\hline A. rubra & & & \\
\hline R3 & 204RU & Nouville, New Zealand & C. Van Hove \\
\hline A. mexicana & & & \\
\hline $\mathbf{X} 1$ & $\mathbf{X} 1$ & California, USA (BR-S-CF) & G. Peters \\
\hline $\begin{array}{l}\text { A. microphylla } \\
\mathrm{M} 2\end{array}$ & M2 & Galápagos, Ecuador (TL-GI-CF) & G. Peters \\
\hline A. filiculoides & & & \\
\hline $\begin{array}{l}\text { F3 } \\
\text { F4 }\end{array}$ & $\begin{array}{l}\text { F3 } \\
\text { FLA }\end{array}$ & $\begin{array}{l}\text { Hawaii, USA (BR-M-CF) } \\
\text { Hillboug, Tampa, Florida, USA }\end{array}$ & $\begin{array}{l}\text { G. Peters } \\
\text { W. Zimmerman }\end{array}$ \\
\hline A. nilotica & & & \\
\hline N1 & $\begin{array}{l}82 \mathrm{NI} / \mathrm{N} 1 \\
/ 5001\end{array}$ & Kosti, Sudan & $\begin{array}{l}\text { Van Hove/Peters } \\
\text { Zimmerman }\end{array}$ \\
\hline $\begin{array}{l}\text { A. pinnata } \\
\text { var. pinnata } \\
\text { P1 }\end{array}$ & P1 & Malaysia (BR-M-CF) & G. Peters \\
\hline $\begin{array}{l}\text { A. pinnata } \\
\text { var. imbricata } \\
13\end{array}$ & JNPI1 & Chisato Mie, Japan & W. Zimmerman \\
\hline
\end{tabular}

- Sources: Dr Gerald Peters, Virginia Commonwealth University, Richmond, Virginia, USA; Dr Charles Van Hove, Universite Catholique de Louvain at Louvain-la-Neuve, Belgium; Dr William Zimmerman, University of Michigan, Dearborn, MI, USA. 
$30 \mathrm{ml} \mathrm{min}^{-1}$; injector temperature, $230^{\circ} \mathrm{C}$; initial column temperature, $130^{\circ} \mathrm{C}$; final temperature, $230^{\circ} \mathrm{C}$; temperature program rate, $4{ }^{\circ} \mathrm{C}$ $\mathrm{min}^{-1}$. These conditions yielded chromatograms containing at least 40 detected components (peaks) between 8 and 20 carbons in length. Each sample was analysed once, except for $A$. rubra which was grown, extracted and analysed on three separate occasions in order to determine experimental variability.

Fatty acids were identified by co-chromatography with reference standards that were available. Major fatty acids, defined as those constituting at least $0.9 \%$ of the total, were confirmed by mass spectrometer (Finnegan $8230 \mathrm{HR}$ ) and by chemical tests (Caudales \& Wells, 1992). Other eluted peaks, comprising the minor fatty acids $(0.03$ to $0.89 \%$ of the total) and trace components (less than $0.03 \%$ ) were confirmed chemically. Chemical tests included those for unsaturated, hydroxy-substituted and cyclopropane fatty acids (Moss, 1979). Reference standards for 21 bacterial fatty acids were obtained from Supelco and 12 branch-chain fatty acids from Applied Science. Equivalent carbon chain length (ECL) was calculated for each peak, and provided further confirmation of identity by reference to ECLs from published reports (Gillan \& Hogg, 1984; Caudales \& Wells, 1992). Unsaturated sites and their isomeric positions were directly determined by mass spectroscopy only in the case of major fatty acids.

Statistical analysis. Eluted fractions from gas chromatography were integrated and quantified as percentages of total peak areas with a Model 4270 Chromatography Data System (Varian Associates). Data were analysed by an Apple III computer running Omnis 3 Database Manager (Blyth Software). Fatty acids were categorized by chemical class (Asselineau, 1962) and subtotals calculated. Variations from the mean were expressed as standard sample deviations and comparisons among means were by the method of Tukey as modified by Snedecor (1966).

\section{Results}

The cellular fatty acid composition of 10 isolates of Azolla cyanobionts included 16 major components accounting for $88.31 \%$ of total fatty acids: the saturated

Table 2. Mean percentage (of the total) of cellular fatty acids of ten strains of cyanobionts from Azolla spp.

\begin{tabular}{|c|c|c|c|c|}
\hline \multicolumn{3}{|c|}{ Fatty acids } & \multicolumn{2}{|c|}{ Mean percentage of total ${ }^{*}$} \\
\hline & Chemical Class & ECL† & Percentage & Rangef \\
\hline \multirow[t]{9}{*}{ A. } & $\begin{array}{l}\text { Saturated, even-carbon } \\
\text { straight chains: }\end{array}$ & & & \\
\hline & $8: 0$ & $8 \cdot 0$ & 0.04 & $0-0.06$ \\
\hline & $10: 0$ & $10 \cdot 0$ & 0.03 & $0-0.05$ \\
\hline & $12: 0$ & $12 \cdot 0$ & $0 \cdot 25$ & $0.12-0.41$ \\
\hline & $14: 0$ & $14 \cdot 0$ & $1 \cdot 10$ & $0.66-1.38$ \\
\hline & $16: 0$ & $16 \cdot 0$ & $38 \cdot 10$ & $35 \cdot 17-42 \cdot 16$ \\
\hline & $18: 0$ & $18 \cdot 0$ & $2 \cdot 33$ & $1 \cdot 20-3 \cdot 55$ \\
\hline & $20: 0$ & 20.0 & $0 \cdot 19$ & $0.10-0.29$ \\
\hline & Class A total & & $42 \cdot 04$ & $39 \cdot 81-45 \cdot 18$ \\
\hline \multirow[t]{8}{*}{ B. } & $\begin{array}{l}\text { Saturated, odd-carbon } \\
\text { straight chains: }\end{array}$ & & & \\
\hline & $9: 0$ & $9 \cdot 0$ & 0.04 & $0-0 \cdot 10$ \\
\hline & $11: 0$ & $11 \cdot 0$ & 0.01 & $0-0.05$ \\
\hline & $13: 0$ & 13.0 & 0.01 & $0-0.04$ \\
\hline & $15: 0$ & $15 \cdot 0$ & 0.48 & $0.24-0.87$ \\
\hline & $17: 0$ & 17.0 & 0.28 & $0 \cdot 14-0.36$ \\
\hline & 19:0 & $19 \cdot 0$ & 0.09 & $0.09-0.20$ \\
\hline & Class B total & & 0.91 & $0.59-1.43$ \\
\hline
\end{tabular}

Table 2. Continued

\begin{tabular}{|c|c|c|c|c|}
\hline \multicolumn{3}{|c|}{ Fatty acids } & \multicolumn{2}{|c|}{ Mean percentage of total* } \\
\hline & Chemical Class & ECL $†$ & Percentage & Range‡ \\
\hline C. & $\begin{array}{l}\text { Unsaturated, straight- } \\
\text { chain acids: } \\
12: 1 \\
13: 1 \\
14: 1 \text { cis-7 } \\
14: 1 \text { cis }-9 \\
16: 4 \\
16: ? \S \\
16: 4 \text { cis }-4 \\
16: 3 \text { cis }-6 \\
16: 1 \text { cis }-7 \\
16: 1 \text { cis }-9 \\
16: 1 \text { trans-9 } \\
16: 1 \text { cis }-11 \\
16: 1 \text { trans }-3 \\
18: 3 \text { cis }-6 \\
18: 4 \text { cis }-6 \\
18: 2 \text { cis }-9 \\
18: 3 \text { cis }-9 \\
18: 1 \text { cis- } 9 \\
18: 1 \text { trans-9 } \\
20: 4 \text { cis-5 } \\
20: 4 \text { cis }-8 \\
20: 2 \text { cis }-11 \\
\text { Class C total }\end{array}$ & $\begin{array}{l}11.8 \\
12.8 \\
13.8 \\
13.9 \\
15.2 \\
15.5 \\
15.55 \\
15.6 \\
15.75 \\
15.8 \\
15.85 \\
15.9 \\
15.95 \\
17.2 \\
17.5 \\
17.7 \\
17.75 \\
17.8 \\
17.85 \\
19.2 \\
19.4 \\
19.6\end{array}$ & $\begin{array}{r}0.93 \\
0.03 \\
0 \cdot 12 \\
2.35 \\
0 \cdot 24 \\
1.36 \\
0.76 \\
2.51 \\
0.92 \\
4.45 \\
0.01 \\
1.96 \\
0.64 \\
0.55 \\
0.19 \\
8.36 \\
16.50 \\
3.81 \\
2.08 \\
0.95 \\
0.25 \\
0.36 \\
49.33\end{array}$ & 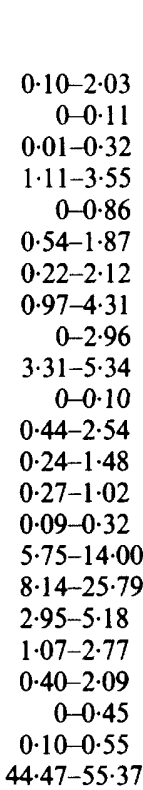 \\
\hline D. & $\begin{array}{l}\text { Hydroxy-substituted: } \\
\text { 20H-10:0 } \\
\text { 30H-10:0 } \\
\text { iso } 30 \mathrm{H}-11: 0 \\
20 \mathrm{H}-12: 0 \\
\text { 30H-12:0 } \\
\text { iso } 30 \mathrm{H}-13: 0 \\
\text { iso } 30 \mathrm{H}-15: 0 \\
\text { iso } 30 \mathrm{H}-17: 0 \\
\text { 30H-17:0 } \\
\text { Class D total }\end{array}$ & $\begin{array}{l}11 \cdot 15 \\
11 \cdot 4 \\
12 \cdot 1 \\
13 \cdot 2 \\
13 \cdot 5 \\
14 \cdot 1 \\
16 \cdot 1 \\
18 \cdot 1 \\
18 \cdot 4\end{array}$ & $\begin{array}{l}0.06 \\
0 \cdot 17 \\
0.02 \\
0.07 \\
0.04 \\
0 \cdot 15 \\
0.04 \\
0.22 \\
0.33 \\
1 \cdot 10\end{array}$ & $\begin{array}{r}0-0.19 \\
0.04-0.39 \\
0-0.13 \\
0-0.22 \\
0-0.14 \\
0.11-0.29 \\
0-0.18 \\
0.01-1.23 \\
0.14-0.40 \\
0.53-2.31\end{array}$ \\
\hline E. & $\begin{array}{l}\text { Branch-chain acids: } \\
\text { iso-13:0 } \\
\text { iso-14:0 } \\
\text { iso-15:0 } \\
\text { anteiso-15:0 } \\
\text { iso-16:0 } \\
\text { iso-17:0 } \\
\text { anteiso-17:0 } \\
\text { iso-19:0 } \\
\text { anteiso-19:0 } \\
\text { Class E total }\end{array}$ & $\begin{array}{l}12 \cdot 6 \\
13 \cdot 6 \\
14 \cdot 6 \\
14 \cdot 7 \\
15 \cdot 6 \\
16 \cdot 6 \\
16 \cdot 7 \\
18 \cdot 6 \\
18 \cdot 7\end{array}$ & $\begin{array}{l}0.09 \\
0.07 \\
0.06 \\
0.08 \\
1.96 \\
0.33 \\
0.19 \\
0.06 \\
0.12 \\
2.96\end{array}$ & $\begin{array}{r}0.01-0.15 \\
0-0.20 \\
0-0.18 \\
0-0.25 \\
0.41-1.96 \\
0.17-0.46 \\
0.10-0.25 \\
0-0.17 \\
0-0.30 \\
1.19-5.44\end{array}$ \\
\hline F. & $\begin{array}{l}\text { Cyclopropane acids: } \\
\text { cyclo-17:0 } \\
\text { cyclo-19:0 } \\
\text { Class } F \text { total }\end{array}$ & $\begin{array}{l}16.9 \\
18.9\end{array}$ & $\begin{array}{l}0.17 \\
0.72 \\
0.89\end{array}$ & $\begin{array}{r}0-0.55 \\
0-1 \cdot 30 \\
0 \cdot 07-1 \cdot 38\end{array}$ \\
\hline G. & $\begin{array}{l}\text { Unsaturated branch- } \\
\text { chained fatty acids: } \\
\text { iso-15:1 } \\
\text { iso- } 17: 1 \\
\text { iso-18:1 } \\
\text { Class G total }\end{array}$ & $\begin{array}{l}14 \cdot 4 \\
16 \cdot 4 \\
17 \cdot 4\end{array}$ & $\begin{array}{l}0.05 \\
0 \cdot 25 \\
0.36 \\
0.66\end{array}$ & $\begin{array}{r}0-0.15 \\
0 \cdot 12-0.40 \\
0 \cdot 10-0.94 \\
0.25-1.42\end{array}$ \\
\hline Un & dentified components & & $2 \cdot 11$ & $0 \cdot 88-3 \cdot 12$ \\
\hline
\end{tabular}

* Mean percentages of total fatty acids.

$\dagger \mathrm{ECL}=$ equivalent (carbon) chain length.

$\ddagger$ Highest and lowest value for each fatty acid in the 10 strains analysed.

$\S$ Component is unsaturated (determined chemically), but Site (or sites) undetermined. 
Table 3. Fatty acid parameters of Azolla cyanobionts significantly different from those of free-living Anabaena and Nostoc cyanobacteria

\begin{tabular}{|c|c|c|c|}
\hline \multirow{2}{*}{$\begin{array}{c}\text { Fatty acid } \\
\text { or } \\
\text { class total } \dagger\end{array}$} & \multirow{2}{*}{$\begin{array}{c}\text { Azolla } \\
\text { cyanobionts }\end{array}$} & \multicolumn{2}{|c|}{ Free-living cyanobacteria* } \\
\hline & & Anabaena & Nostoc \\
\hline $\begin{array}{l}\text { Class A total } \\
14: 0 \\
16: 0 \ddagger \\
18: 0\end{array}$ & $\begin{array}{r}42.04 \pm 1.77 \mathrm{a} \\
1.10 \pm 0.26 \mathrm{a} \\
38.10 \pm 1.90 \mathrm{a} \\
2.33 \pm 0.74 \mathrm{a}\end{array}$ & $\begin{array}{r}32.11 \pm 2.45 \mathrm{~b} \\
0.44 \pm 0.15 \mathrm{~b} \\
30.55 \pm 2.25 \mathrm{~b} \\
0.77 \pm 0.39 \mathrm{~b}\end{array}$ & $\begin{array}{r}25.02 \pm 2.15 \mathrm{c} \\
0.28 \pm 0.14 \mathrm{~b} \\
23.23 \pm 2.17 \mathrm{c} \\
1.27 \pm 0.59 \mathrm{ab}\end{array}$ \\
\hline $\begin{array}{c}\text { Class } C \text { total } \\
14: 1 \text { cis }-7 \ddagger \\
16: 1 \text { cis }-9 \ddagger \\
16: 1 \text { trans }-9 \\
16: 1 \text { trans }-3 \\
18: 2 \text { cis }-9 \\
18: 1 \text { trans }-9 \\
20: 4 \text { cis }-5\end{array}$ & $\begin{array}{r}49.32 \pm 3.87 \mathrm{a} \\
0.12 \pm 0.14 \mathrm{a} \\
4.45 \pm 0.62 \mathrm{a} \\
0.01 \pm 0.03 \mathrm{a} \\
0.64 \pm 0.35 \mathrm{a} \\
8.36 \pm 2.37 \mathrm{a} \\
2.08 \pm 0.61 \mathrm{a} \\
0.95 \pm 0.52 \mathrm{a}\end{array}$ & $\begin{array}{c}59.21 \pm 4.99 \mathrm{ab} \\
2.50 \pm 1.94 \mathrm{~b} \\
6.53 \pm 4.72 \mathrm{a} \\
4.02 \pm 2.71 \mathrm{~b} \\
0 \quad \mathrm{~b} \\
10.16 \pm 2.87 \mathrm{ab} \\
0.92 \pm 0.51 \mathrm{~b} \\
0.06 \pm 0.11 \mathrm{~b}\end{array}$ & 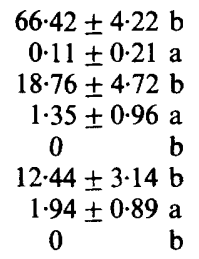 \\
\hline $\begin{array}{l}\text { Class } E \text { total } \\
\text { cyclo } 19: 0\end{array}$ & $\begin{array}{l}2.95 \pm 1.54 \mathrm{a} \\
0.72 \pm 0.43 \mathrm{a}\end{array}$ & $\begin{array}{l}3.77 \pm 1.15 b \\
0.03 \pm 0.05 b\end{array}$ & $\begin{array}{l}2.31 \pm 0.64 \mathrm{a} \\
0.05 \pm 0.08 \mathrm{~b}\end{array}$ \\
\hline $\begin{array}{l}\text { Class G total } \\
\text { iso-15:1 }\end{array}$ & $\begin{array}{l}0.66 \pm 0.35 \mathrm{a} \\
0.05 \pm 0.05 \mathrm{a}\end{array}$ & $\begin{array}{l}1.01 \pm 0.76 \mathrm{a} \\
0.34 \pm 0.64 \mathrm{a}\end{array}$ & $\begin{array}{l}2.61 \pm 1.45 b \\
2.05 \pm 1.49 b\end{array}$ \\
\hline Total 20-carbons & $1.84 \pm 0.74 \mathrm{a}$ & $0.53 \pm 0.48 b$ & $0.29 \pm 0.16 \mathrm{~b}$ \\
\hline $\begin{array}{r}\text { Ratio class } \mathrm{C} / \mathrm{A}+\mathrm{B} \\
\mathrm{C} / \mathrm{A} \ddagger\end{array}$ & $\begin{array}{l}1 \cdot 15 \pm 0.13 \mathrm{a} \\
1 \cdot 17 \pm 0 \cdot 11 \mathrm{a}\end{array}$ & $\begin{array}{l}1.80 \pm 0.20 \mathrm{~b} \\
1.84 \pm 0.22 \mathrm{~b}\end{array}$ & $\begin{array}{l}2.57 \pm 0.40 \mathrm{c} \\
2.66 \pm 0.40 \mathrm{c}\end{array}$ \\
\hline
\end{tabular}

* Data from Caudales \& Wells (1992)

$\dagger$ Percentage of total \pm standard deviation. Averages in each row not followed by the same letter are statistically different $(P \leqslant 0.05)$.

$\ddagger$ Parameter of taxonomic value in distinguishing free-living Anabaena and Nostoc (Caudales \& Wells, 1992).

$14: 0,16: 0$ and $18: 0$ carbon chains; the unsaturated straight-chained $12: 1,14: 1$ cis-7, 16:1 cis $7,16: 1$ cis-9, $16: 1$ cis-11, 16:3 cis-6, 18:2 cis-9, 18:3 cis-9, 18:1 cis and trans-9, and 20:4 cis-5; and the branch-chained iso-16:0 (Table 2). Also included was an unsaturated 16-carbon (ECL 15.5) with unsaturation sites undetermined. The most abundant component in the group was the 16:0, with a mean concentration of $38.10 \%$ of the total, and ranging between $35 \cdot 17$ and $42 \cdot 16 \%$.

There were 38 minor fatty acid components detected and identified, comprising $10.3 \%$ of the total, and 4 trace-level components. These included hydroxy-substituted acids $(1 \cdot 10 \%)$, branch-chains in addition to the iso$16: 0(1.96 \%$ of a total of $2.96 \%)$, and cyclopropane acids $(0.89 \%)$ (Table 2$)$.

Comparing the fatty acid composition of Azolla cyanobionts with those previously published for the freeliving cyanobacteria Anabaena and Nostoc, cyanobionts differed from one or both of the cyanobacteria in the composition of 12 specific fatty acids, including the 4 previously identified as important in the differentiation of Anabaena and Nostoc (Caudales \& Wells, 1992). Values for $16: 0$, total class A, and the ratio of classes $\mathrm{C} / \mathrm{A}$ in Azolla cyanobionts were significantly different from those in Anabaena and Nostoc (Table 3). Percentages for $16: 1$ cis-9 and iso-15:1 were similar to those reported for
Anabaena, but not for Nostoc; and the percentage of $14: 1$ cis-7 was similar to Nostoc, but not to Anabaena. Percentages of the 14:0, 16:1 trans-3, 20:4 cis-5, and cyclo-19:0 were also different in the cyanobiont from those in both Anabaena and Nostoc, as well as percentages for classes $\mathrm{C}$ and $\mathrm{G}$ (Table 3).

One fatty acid, iso-15:1, was either absent or present as a minor component in Azolla cyanobionts, while in Nostoc it constituted a major component (Caudales \& Wells, 1992). Two fatty acids, $16: 1$ trans 3 and iso $3-\mathrm{OH}$ 13:0, were present in cyanobionts but had not been previously reported in Anabaena or Nostoc. The 16:1 trans-9 was also either absent or present in only trace amounts in the cyanobionts.

Poly-unsaturated acids in the Azolla cyanobionts averaged $30.67 \%$ of the total, compared to $33.02 \%$ and $32.90 \%$ in Anabaena and Nostoc, respectively (data not shown). The most abundant were the $18: 3 \mathrm{cis}-9$ and the $18: 2 \mathrm{cis}-9$. The composition of total mono-unsaturated acids in cyanobionts was $17.30 \%$, compared to $24.74 \%$ and $32.23 \%$ for Anabaena and Nostoc. The mean percentage of combined 16-carbon fatty acids was $50.95 \%$.

Control preparations of cellular debris from Azolla and of bacterial contaminants from Azolla cavities yielded no fatty acid peaks in their respective chromatograms. Variations (standard deviations) in fatty acid percentages of the one cyanobiont repeatedly analysed ( $A$. rubra) were within the ranges for the group in general.

\section{Discussion}

Oxygenic photosynthetic cyanobacteria have the same gross membrane organization as other Gram-negative prokaryotic eubacteria except for their thylakoid membrane sacs which house the electron transport chain, chlorophyll $a$ and reaction centers (Drews \& Weckesser, 1982; Golecki \& Drews, 1982). Fatty acid composition is also different in cyanobacteria, possibly due in part to these photosynthetic membrane characteristics. In eubacteria, branch-chain fatty acids are major constituents, and straight chains may constitute up to $10 \%$ of total fatty acids (Kaneda, 1991). In the cyanobacteria, the 16- and 18-carbon straight chains were the major fatty acids, similar to those in plants (Christie, 1987), and the branch-chains were minor components. Another difference is the high percentage of polyunsaturated acids in cyanobacteria compared to their absence in most eubacteria (Johns \& Perry, 1977; De Long \& Yayanos, 1986). These fundamental differences in composition may have a direct bearing on the balance and fluidity of membrane lipids.

Cyanobionts are enclosed in dorsal cavities of Azolla fronds where the environmental medium and light 
quality differs from that surrounding free-living cyanobacteria. Fatty acid composition of the cyanobionts may be significantly affected by these factors, possibly accounting for their differences with free-living cyanobacteria. Strong illumination, for example, during growth of Anabaena variabilis stimulated desaturation of 18:1 and 18:2 fatty acids (Sato \& Murata, 1981). Differences in morphology may also influence fatty acid composition. Up to $30 \%$ of the cells of cyanobionts may be heterocysts (Hill, 1975) compared to $5-10 \%$ in freeliving cyanobacteria (Fogg et al., 1973). Fatty acid composition of cyanobionts may also be influenced by host species (study in progress).

Plant debris or other bacteria may also have contaminated the preparations of Azolla cyanobacteria. Although low levels of such contaminants (as determined by microscopy) remained after the purification procedure, their biomass was demonstrated to be too small to contribute to fatty acid profiles of the cyanobacteria. Only trace levels of fatty acids were obtained from plant or bacterial preparations, 2 to 3 orders of magnitude more concentrated than levels generally found in cyanobacterial preparations.

It is possible that the cyanobacteria isolated from Azolla are a mixed population (Gebhardt \& NierzwickiBauer, 1991), including epiphytes, rather than pure cultures. There is evidence that restriction fragment analysis of cultivable cyanobionts does not correspond to that of freshly isolated cells from Azolla cavities (Meeks et al., 1988). However, since microscopic observations of our samples indicated morphological uniformity, and since the issue is unresolved, we assumed the cultures were essentially homogenous.

A comparison of fatty acid profiles of Azolla cyanobionts with those previously published for the free-living cyanobacteria Anabaena and Nostoc, indicated there were at least 19 factors - individual fatty acids, class totals, and ratios - which were statistically different (Table 3). Nine of the 19 factors were unique to the Azolla cyanobionts; i.e. different from both Anabaena and Nostoc. Five were different from only Anabaena, and five from only Nostoc. A numerical tally of differentiating factors, therefore, implies that cyanobionts were as different from Anabaena as from Nostoc.

Among the differentiating factors, the largest components were class $\mathrm{A}$ and $\mathrm{C}$ totals, accounting for over $90 \%$ of total fatty acids in Azolla cyanobionts. The composition of class $\mathrm{A}$ in the cyanobionts was different from both Anabaena and Nostoc, and class C was different from that of Nostoc only. Thus, an analysis of differentiating factors of quantitative importance indicates a greater resemblance to Anabaena than to Nostoc.

A third interpretion of the data, centering on the existence of 9 factors unique to the Azolla cyanobionts, suggests that fatty acid composition of the cyanobionts is sufficiently different from both Anabaena and Nostoc to hypothesize their constituting a distinct taxonomic grouping. This hypothesis would be at variance with conclusions based solely on morphological evidence (Caudales et al., 1990), and on two RFLP studies (Meeks et al., 1988; Plazinski et al., 1990) that cyanobionts are more closely related to Nostoc than to Anabaena.

The authors acknowledge the contributions of Dr Gerald Peters of the Virginia Commonwealth University in Richmond, VA, USA, Dr Charles Van Hove of the Universite Catholique de Louvain at Louvain-la-Neuve, Belgium, Dr William Zimmerman of the University of Michigan, Dearborn, MI, USA, and Drs Ellen Braun-Howland and Sandra Nierzwicki-Bauer of Rensselaer Polytechnic Institute, Troy, NY, USA for providing some of the Azolla plants used in this study. We would like to thank Dr Robert Moreau from the USDA in Philadelphia, PA, USA and Dr William J. Zimmerman for critical reading of the manuscript.

\section{References}

Asselineau, J. (1962). The Bacterial Lipids. San Francisco: HoldenDay.

Caudales, R., Antoine, A. D. \& Vasconcelos, A. C. (1990). Morphology and life cycle of the nitrogen-fixing cyanobionts in the seven Azolla species. In Nitrogen Fixation: Achievements and Objectives. Proceedings of the 8th International Congress of Nitrogen Fixation, p. 540. Edited by P. M. Gresshoff, L. Evans Roth, G. Stacey \& W. E. Newton. New York: Chapman \& Hall.

Caudales, R. \& Wells, J. M. (1992). Differentiation of the free-living Anabaena and Nostoc cyanobacteria on the basis of fatty acid composition. International Journal of Systematic Bacteriology 42, 246 251.

CASTENholz, R. W. (1989). Nostocales. In Bergey's Manual of Systematic Bacteriology, vol. 3, pp. 1780-1789. Edited by J. T. Staley, M. P. Bryant, N. Pfennig \& J. G. Holt. Baltimore: Williams \& Wilkins.

CHRISTIE, W. W. (1987). High-performance Liquid Chromatography And Lipids, a Practical Guide, pp. 48-49. New York: Pergamon Press.

DE LoNG, E. F. \& Yayanos, A. A. (1986). Biochemical function and ecological significance of novel bacterial lipids in deep sea prokaryotes. Applied and Environmental Microbiology 51, 730-737.

DREWs, G. \& WECKESSER, J. (1982). Function, structure and composition of cell walls and external layers. In The Biology of Cyanobacteria. pp. 333-357. Edited by N. G. Carr \& B. A. Whitton. Berkeley: University of California Press.

FogG, G. E., Steward, W. D. P., Fay, P. \& Walsby, B. (1973). The Blue-Green Algae. New York: Academic Press.

GeBHARDT, J. S. \& NiERZWICKI-BAUER, S. A. (1991). Identification of a common cyanobacterial symbiont associated with Azolla spp. through molecular and morphological characterization of free-living and symbiotic cyanobacteria. Applied and Environmental Microbiology 57, 2141-2146.

GeITLER, L. (1932). Cyanophyceae. In Rabenhorst's Krypogamenflora von Deutschland, Osterreich und der Schweiz, vol. 14. Edited by R. Kolkwitz. Leipzig: Akademische Verlagsgesellschaft.

Gillan, F. T. \& HoGG, R. W. (1984). A method for the estimation of bacterial biomass and community structure in mangrove-associated sediments. Journal of Microbiological Methods 2, 275-293.

GoleCKI, J. R. \& DREWS, G. (1982). Supramolecular organization and composition of membranes. In The Biology of Cyanobacteria, pp. 333-357. Edited by N. G. Carr \& B. A. Whitton. Berkeley: University of California Press.

HiLl, D. J. (1975). The pattern of development of Anabaena in the Azolla-Anabaena symbiosis. Planta 122, 179-184. 
Johns, R. B. \& Perry, G. J. (1977). Lipids of the marine bacterium Flexibacter polymorphus. Archives of Microbiology 114, 267-271.

KANEDA, T. (1991). Iso- and anteiso fatty acids in bacteria: biosynthesis, function, and taxonomic significance. Microbiological Reviews $55,288-302$.

KIRCHNER, O. (1900). Nostocacea: In Naturliche Pflanzenfamilien, 1 Teil, 4 Abt, pp. 70-72. Edited by A. Engler \& K. Prant. Leipzig: Wilhelm Englemann.

Lumpkin, T. A. \& PlucknetT, D. L. (1982). Botany and ecology. In Azolla as a Green Manure: Use and Management in Crop Production, pp. 15-38. Westview Tropical Series, no. 5. Boulder, Colerado: Westview Press.

Meeks, J. C., JosePH, C. M. \& Haselkorn, R. (1988). Organization of nif genes in cyanobacteria in symbiotic association with Azolla and Anthoceros. Archives of Microbiology 150, 61-71.

Meeks, J. C. (1990). Cyanobacterial-Bryophyte Associations. CRC Handbook of Symbiotic Cyanobacteria. pp. 43-63. Edited by A. M. Rai. Boca Raton: CRC Press.

Moss, C. W. (1979). Analysis of cellular fatty acids of bacteria by gasliquid chromatography. In Legionnaires: the Disease, Bacteria and Methodology, pp. 117-122. Edited by G. L. Jones \& G. A. Herbert. Atlanta: US Dept. of Health, Education \& Welfare, Centers for Disease Control.

Peters, G. A. \& Meeks, J. C. (1989). The Azolla-Anabaena symbiosis: basic biology. Annual Review of Plant Physiology, vol. 40, pp. 193210. New York: Academic Press.

Plazinski, J., Zheng, G., Tailor, R., Croft, L., Rolfe, B. G. \&
GuNNING, B. E. S. (1990). DNA probes show genetic variation in cyanobacterial symbionts of the Azolla fern and closer relationship to free-living Nostoc strains than to free-living Anabaena strains. Applied and Environmental Microbiology 56, 1263-1270.

Rippka, R., Deruelles, J., Waterbury, J. B., Herdman, M. \& STANIER, R. Y. (1979). Genetic assignments, strain histories and properties of pure cultures of cyanobacteria. Journal of General Microbiology 111, 1-61.

RIPPKA, R. (1988). Recognition and identification of cyanobacteria. Methods in Enzymology 167, 28-67.

SATo, N. \& MURATA, N. (1981). Studies on the temperature-shiftinduced desaturation of fatty acids in monogalactosyl diacylglycerol in blue-green algae (Cyanobacterium), Anabaena variabilis. Plant and Cell Physiology 22, 1043-1050.

SNEDECOR, G. W. (1966). Statistical Methods, 5th Edn. Ames, Iowa: Iowa State University Press.

Strasburger, E. (1873). Ueber Azolla, pp. 76-86. Leipzig: Verlag von Ambr. Abel.

Strasburger, E. (1884). Das Botanische Practicum. Jena \& Leipzig: Gustav Fischer.

Van Hove, C., Diara, H. F. \& Godard, P. (1983). Azolla in West Africa (Azolla Project of the West Africa Rice Development Association and Belgium Administration for Development and Cooperation). Brussels.

VASIShTA, P. C. (1975). Vascular cryptogams (Pteridophyta). In Botany for Degree Students, vol. IV, pp. 443-454. New Delhi: S. Chand \& Co. (Pvt). 